\title{
THE EFFECT OF MICROSTRUCTURE ON MECHANICAL PROPERTIES OF DIRECTIONALLY SOLIDIFIED $\mathrm{Al}_{2} \mathrm{O}_{3} / \mathrm{ZrO}_{2}\left(\mathrm{Y}_{2} \mathrm{O}_{3}\right)$ EUTECTIC
}

\author{
Ali Sayir and Serene C. Farmer \\ NASA Glenn Research Center - Cleveland, Ohio.
}

\begin{abstract}
The eutectic architecture of a continuous reinforcing phase within a higher volume fraction phase or matrix can be described as a naturally occurring in-situ composite. Here we report the results of experiments aimed at identifying the sources of high temperature creep resistance and high levels of strength in a two phase $\mathrm{Al}_{2} \mathrm{O}_{3} / \mathrm{ZrO}_{2}\left(\mathrm{Y}_{2} \mathrm{O}_{3}\right)$ system. The mechanical properties of two phase $\mathrm{Al}_{2} \mathrm{O}_{3} / \mathrm{ZrO}_{2}\left(\mathrm{Y}_{2} \mathrm{O}_{3}\right)$ eutectic are superior to those of either constituent alone due to strong constraining effects provided by the coherent interfaces and microstructure. The $\mathrm{Al}_{2} \mathrm{O}_{3} / \mathrm{ZrO}_{2}\left(\mathrm{Y}_{2} \mathrm{O}_{3}\right)$ eutectic maintains a low energy interface resulting from directional solidification and can produce strong and stable reinforcing phase/matrix bonding. The phases comprising a eutectic are thermodynamically compatible at higher homologous temperatures than man-made composites and as such offer the potential for superior high temperature properties.
\end{abstract}




\title{
THE EFFECT OF MICROSTRUCTURE ON MECHANICAL PROPERTIES OF DIRECTIONALLY SOLIDIFIED $\mathrm{Al}_{2} \mathrm{O}_{3} / \mathrm{ZrO}_{2}\left(\mathrm{Y}_{2} \mathrm{O}_{3}\right)$ EUTECTIC
}

\author{
Ali Sayir* and Serene C. Farmer \\ NASA Glenn Research Center - Cleveland, Ohio.
}

\section{INTRODUCTION}

The eutectic architecture, a continuous reinforcing phase within a higher volume fraction phase, can be described as a naturally occurring in-situ composite. In-situ composites exhibit mechanical properties intermediate between monolithic materials and man-made composites. ${ }^{1-3}$ The phases comprising a eutectic are thermodynamically compatible at higher homologous temperatures than man-made composites and as such offer the potential for superior high temperature properties. ${ }^{4,5}$

The mechanical properties of two phase eutectics can be superior to that of either constituent alone due to strong constraining effects provided by the interlocking microstructure. There is no detailed understanding of why this occurs in the directionally solidified two phase material. Heterophase interfaces characteristic of oxide-oxide eutectics have not been widely investigated. In this paper, we report the results of mechanical property experiments aimed at identifying the sources of high temperature creep resistance and high levels of strength in a two phase eutectic system. The $\mathrm{Al}_{2} \mathrm{O}_{3} / \mathrm{ZrO}_{2}\left(\mathrm{Y}_{2} \mathrm{O}_{3}\right)$ eutectic is an ideal material for study because this system consists of a highly creep resistant material $\left(\mathrm{Al}_{2} \mathrm{O}_{3}\right)$ in combination with yttria stabilized cubic zirconia $\left(\mathrm{c}-\mathrm{ZrO}_{2}\left(\mathrm{Y}_{2} \mathrm{O}_{3}\right)\right.$ ), a material having very poor creep properties. The constituent phases of the $\mathrm{Al}_{2} \mathrm{O}_{3} / \mathrm{ZrO}_{2}\left(\mathrm{Y}_{2} \mathrm{O}_{3}\right)$ eutectic, $\mathrm{Al}_{2} \mathrm{O}_{3}$ and $\mathrm{c}-\mathrm{ZrO}_{2}\left(\mathrm{Y}_{2} \mathrm{O}_{3}\right)$ ), have been studied extensively and reliable data is available. Thus, the 



\section{EXPERIMENTAL}

Growth and characterization of single crystals and eutectics are described in the literature ${ }^{6}$ in detail. An abbreviated description will be reported here. The laser heated float zone (LHFZ) technique provides a means to efficiently produce and record the underlying growth phenomena associated with two phase structures. The heating source is a coherent $\mathrm{CO}_{2}$-laser beam (FH-1500-Carbon Dioxide Laser $r^{\#}$ ) split into four beams, $90^{\circ}$ apart from each other. Each beam is focused onto the molten zone at the top surface of a polycrystalline source rod located in the center of the processing chamber. These opposing beams are mechanically converted into opposing laser raster lines and during growth the source rod is moved vertically through the laser beam. The maximum available laser power is 600 watts, but only a small fraction of this power was needed as the radiation from the $\mathrm{CO}_{2}$-laser (wavelength $=10.6 \mu \mathrm{m}$ ) is effectively absorbed in the oxides. ${ }^{7}$ The molten zone temperature was measured in the infrared radiation region with an Infrared Thermal Monitor,++ and the output was used to control the laser power. To initiate directional solidification of the eutectic, a seed of single crystal sapphire $(<0001>$ direction) was lowered onto the molten liquid until wetting occurred. Growth of off-axis sapphire was accomplished using an off-axis seed of the desired orientation. Crystallographic orientation of single crystal fibers was verified using $\mathrm{x}$-ray diffraction. All experiments were conducted in air. Neither the crystal nor the source rod was rotated.

Source rods were prepared using high purity $\left(99.99 \%\right.$ pure) polycrystalline $\mathrm{Al}_{2} \mathrm{O}_{3}$ powder, CERAC/pure ${ }^{\dagger}\left(325\right.$ mesh), and $99.999 \%$ pure $\mathrm{ZrO}_{2}$ and $\mathrm{Y}_{2} \mathrm{O}_{3}$ powders from Alfa Aesar $\otimes^{\circledR}$. This powder was blended with $5 \mathrm{w} \%$ Methocel $20-231^{\circledast}$ plus glycerin in a water based slurry. The slurry was then degassed overnight with a moderate vacuum $\left(\sim 70 \times 10^{3} \mathrm{~Pa}\right)$ to achieve a high viscosity paste.

\footnotetext{
\# PRC CORP., Landing, NJ 0785.

++ Vanzetti Systems, Stoughten, MA 02072.

$\dagger$ Ceralox Corp., Tucson, AZ 08576.

(8) The Dow Chemical Company, Midland, MI 48674.
} 
The paste was extruded using a modified hypodermic syringe. The rods were furnace dried in air at $200^{\circ} \mathrm{C}$ for one hour and placed in the LHFZ apparatus without any pre sintering.

The tensile strength of rods 200 to $600 \mu \mathrm{m}$ in diameter were tested in air by placing them in a $\mathrm{MoSi}_{2}$ furnace (CM Inc., Bloomfield, NJ) with a $2.5 \mathrm{~cm}$ hot zone. All tested samples fractured within this $2.5 \mathrm{~cm}$ length. For static load creep studies, the rods were dead weight loaded at temperature using cold grips in high vacuum $\left(\sim 10^{-1} \mathrm{~Pa}\right)$ at $1400^{\circ} \mathrm{C}$ in a tantalum element furnace with a hot zone of $1.5 \mathrm{~cm}$. Linear variable differential transducers were used to measure the elongation. 


\section{RESULTS AND DISCUSSION}

Creep properties are critically dependent on the crystallographic orientation of the test material with respect to the applied load. The time-dependent creep strain for directionally solidified $\mathrm{Al}_{2} \mathrm{O}_{3} / \mathrm{ZrO}_{2}\left(\mathrm{Y}_{2} \mathrm{O}_{3}\right)$ and for three different orientations of sapphire were measured in a vacuum at $1400^{\circ} \mathrm{C}$. Creep strain results for directionally solidified $\mathrm{Al}_{2} \mathrm{O}_{3} / \mathrm{ZrO}_{2}\left(\mathrm{Y}_{2} \mathrm{O}_{3}\right)$, c-axis sapphire, and two off-axis sapphire rods $\left(15^{\circ}\right.$ and $45^{\circ}$ from the $<0001>$ direction) are presented in Figure 1 . As expected c-axis sapphire does not deform at this temperature. However, the creep deformation of $15^{\circ}$ off-axis sapphire is severe, almost $5 \%$ in 10 minutes. The deformation of $45^{\circ}$ off-axis is even more severe. Thus, for any structural applications at these load levels, off-axis sapphire is unacceptable. In contrast, at the applied stress of $300 \mathrm{MPa}$ the creep deformation of directionally solidified $\mathrm{Al}_{2} \mathrm{O}_{3} / \mathrm{ZrO}_{2}\left(\mathrm{Y}_{2} \mathrm{O}_{3}\right)$ remained well below that of the $15^{\circ}$ and $45^{\circ}$ off-axis sapphire. Furthermore, the minimum creep rate for $45^{\circ}$ off-axis grown sapphire and $\mathrm{Al}_{2} \mathrm{O}_{3} / \mathrm{ZrO}_{2}\left(\mathrm{Y}_{2} \mathrm{O}_{3}\right)$ eutectic was determined for a wide range of stress levels and is depicted in Fig. 2. At a stress level of 250 to $300 \mathrm{MPa}$, the creep rate of $\mathrm{Al}_{2} \mathrm{O}_{3} / \mathrm{ZrO}_{2}\left(\mathrm{Y}_{2} \mathrm{O}_{3}\right)$ eutectic constantly decreases with time, giving the appearance of a primary or transient creep stage up to $5 \%$ or more strain. The minimum creep rates shown in Fig. 2 indicate that the creep resistance of $\mathrm{Al}_{2} \mathrm{O}_{3} / \mathrm{ZrO}_{2}\left(\mathrm{Y}_{2} \mathrm{O}_{3}\right)$ eutectic is an order of magnitude better than $45^{\circ}$ off-axis sapphire. Garcia et al. ${ }^{8}$ and Martinez-Fernandez et al. ${ }^{9}$ studied creep properties of $\mathrm{c}-\mathrm{ZrO}_{2}\left(\mathrm{Y}_{2} \mathrm{O}_{3}\right)$ as a function of $\mathrm{Y}_{2} \mathrm{O}_{3}$ content and found that the steady state creep rate of $\mathrm{c}-\mathrm{ZrO}_{2}\left(\mathrm{Y}_{2} \mathrm{O}_{3}\right)$ of comparable composition is an order magnitude higher than the $\mathrm{Al}_{2} \mathrm{O}_{3} / \mathrm{ZrO}_{2}\left(\mathrm{Y}_{2} \mathrm{O}_{3}\right)$ eutectic shown in Fig.2.

The majority of microstructures of $\mathrm{Al}_{2} \mathrm{O}_{3} / \mathrm{ZrO}_{2}\left(\mathrm{Y}_{2} \mathrm{O}_{3}\right)$ eutectics had very small size lamellae (in many cases $\leq 0.2 \mu \mathrm{m}$ ), Figs. 3 and 4 . The small lamella size observed in this material is comparable to the grain size observed in high strength monolithic ceramics produced by nano-scale mixing. In contrast to $\mathrm{Al}_{2} \mathrm{O}_{3} / \mathrm{ZrO}_{2}\left(\mathrm{Y}_{2} \mathrm{O}_{3}\right)$ eutectic, the monolithic ceramics with small grain size have limited high temperature creep resistance. The results presented in Figs. 1 and 2 in conjunction with the 
accompanying microstructures (Figs. 3, and 4) demonstrate that one can achieve high temperature creep resistance with a submicron size microstructure. The results presented in Figs. 1 through 4 require further explanation and questions naturally arise as to the effect of the directional solidification microstructure on the creep properties of $\mathrm{c}-\mathrm{ZrO}_{2}\left(\mathrm{Y}_{2} \mathrm{O}_{3}\right)$ in a two phase eutectic. What is the role of the lamella and the nature of the heterophase boundary? Is the trend toward improved creep behavior an intrinsic characteristic of two phase directionally solidified microstructures? Here, a general discussion of observations on the creep resistance and microstructure of $\mathrm{Al}_{2} \mathrm{O}_{3} / \mathrm{ZrO}_{2}\left(\mathrm{Y}_{2} \mathrm{O}_{3}\right)$ eutectics is presented in order to convey two distinctive characteristics of directionally solidified $\mathrm{Al}_{2} \mathrm{O}_{3} / \mathrm{ZrO}_{2}\left(\mathrm{Y}_{2} \mathrm{O}_{3}\right)$ eutectic. First, the effect of heterophase boundaries and crystal orientation are discussed. Subsequently, the residual stress-state and the lamellae size effect on creep resistance are presented.

The microstructure and orientation relationship between phases in the $\mathrm{Al}_{2} \mathrm{O}_{3} / \mathrm{ZrO}_{2}\left(\mathrm{Y}_{2} \mathrm{O}_{3}\right)$ system varies as a function of composition and/or growth rate. Eutectics made without yttria additions are fully lamellar. Microstructures vary from lamellar to faceted rod as the yttria content or growth rate is substantially increased. Typical microstructures of $\mathrm{Al}_{2} \mathrm{O}_{3} / \mathrm{ZrO}_{2}\left(8.5 \mathrm{~m} / \mathrm{oY}_{2} \mathrm{O}_{3}\right)$ eutectics are shown in Fig. 3 (lamellar) and Fig.4 (rod, achieved at rapid growth rates). The $\mathrm{Al}_{2} \mathrm{O}_{3} / \mathrm{ZrO}_{2}\left(\mathrm{Y}_{2} \mathrm{O}_{3}\right)$ eutectic in both cases has a well defined colony microstructure. The colony center consists of fine $\mathrm{ZrO}_{2}$ lamellae (rods) growing parallel to the growth axis within \pm 10 degrees. The $\mathrm{c}-\mathrm{ZrO}_{2}\left(\mathrm{Y}_{2} \mathrm{O}_{3}\right)$ lamellae curve toward the colony boundaries (as can be seen in longitudinal sections) and maintain an angle close to normal to the local growth front. The lamellae coarsen as the boundary is approached and in the larger intercolony boundaries, $\mathrm{c}-\mathrm{ZrO}_{2}\left(\mathrm{Y}_{2} \mathrm{O}_{3}\right)$ forms discrete precipitates.

Figure. 5 shows strict alignment of the lamellae axes between $\mathrm{Al}_{2} \mathrm{O}_{3}$ and $\mathrm{c}-\mathrm{ZrO}_{2}\left(\mathrm{Y}_{2} \mathrm{O}_{3}\right)$ and the high aspect ratio of both phases as occurs at the outer surface. The large aspect ratio, Fig. 5 , is expected to contribute to creep resistance and high temperature microstructural stability. In highly ordered eutectic regions at the surface and within central portions of the colonies, the $\mathrm{ZrO}_{2}$ has a well-defined 
habit (Figure 6a). Strain contrast at the interface is visible as a function of orientation. As the $\mathrm{ZrO}_{2}$ deviates from the habit plane, Fib. $6 \mathrm{~b}$, the interface becomes undulating and with further deviation the faceted rod morphology breaks down. The sapphire phase within a colony is continuous. However, low angle boundaries in both $\mathrm{c}-\mathrm{ZrO}_{2}\left(\mathrm{Y}_{2} \mathrm{O}_{3}\right)$ and $\mathrm{Al}_{2} \mathrm{O}_{3}$ occur where two colonies meet, Fig. $6 \mathrm{c}$. The $\mathrm{Al}_{2} \mathrm{O}_{3} / \mathrm{ZrO}_{2}\left(\mathrm{Y}_{2} \mathrm{O}_{3}\right)$ eutectic examined as part of this study maintain a consistent [0001] alumina. However, the zirconia orientation varies.

The intrinsic stability of directionally solidified ceramics at elevated temperatures is derived from their solidification characteristic near-equilibrium conditions and the formation of low energy interphase boundaries. An understanding of the orientation relationship and crystallography of the interphase will aid in the understanding of superior creep resistance. Samples used in the creep studies consist of alumina and cubic zirconia phases having an orientation relationship best described by the electron diffraction data as:

$\{\overline{2} 110\} \|\{200\} \quad$ interface plane $[0001] \|<011>$ growth axis

This differs from the orientation relationship defined by Mazerolles et al. ${ }^{13}$ for alumina and tetragonal zirconia eutectics which contained considerably less $\mathrm{Y}_{2} \mathrm{O}_{3}$ stabilizer. Deviation from exact alignment of [0001] along the sample axis occurs. Adjacent colonies are misoriented by several degrees with respect to one another. Larger deviations occur in regions of maximum growth front curvature. Additionally, the alignment of $<110>$ along [0001] varies. Deviations of $2^{\circ}$ were observed in electron diffraction patterns.

The establishment of a low energy interfacial relationship between $\mathrm{Al}_{2} \mathrm{O}_{3}$ and $\mathrm{c}-\mathrm{ZrO}_{2}\left(\mathrm{Y}_{2} \mathrm{O}_{3}\right)$ phases is expected to have a significant effect on the creep properties. The interfaces in $\mathrm{Al}_{2} \mathrm{O}_{3} / \mathrm{ZrO}_{2}\left(\mathrm{Y}_{2} \mathrm{O}_{3}\right)$ eutectic system, as in other oxide systems, ${ }^{13,14}$ have homopolar surfaces where they share a common 
oxygen plane. This leads to electrostatic bonding across the boundary and indicates that the two phases are bonded strongly at the interfaces even at high temperatures. Low energy heterophase interfaces e established during eutectic solidification produce strong and stable reinforcing phase/matrix bonding which contributes to high temperature creep resistance and, as will be discussed below, high temperature strength. This result is one of the most intriguing aspects of this research since it justifies the inclusion in future work of systems in which one or both of the constituent phases has non-optimal creep resistance. It is appealing to note that a group of oxide eutectic systems likeNiO-CaO ${ }^{15}, \mathrm{NiO}-\mathrm{Y}_{2} \mathrm{O}_{3}{ }^{16}, \mathrm{Al}_{2} \mathrm{O}_{3}-\mathrm{ZrO}_{2}\left(\right.$ cubic) ${ }^{17}$ and $\mathrm{Fe}_{2} \mathrm{O}_{3}-\mathrm{Al}_{2} \mathrm{O}_{3}{ }^{18}$ also maintain analogous orientation relationships attributable to in homopolar surfaces at the interfaces. A generalization about the lowest energy interfaces for directionally solidified oxide systems should however be avoided because there is a paucity of experimental research and a number of eutectic systems change interface relationships readily as a function of growth conditions.

Further elucidation of superior creep resistance can be achieved by discussing the residual stressstate, and dislocation characteristics of the individual phases. In eutectic systems significant residual stresses may build up during processing as the sample cools from the solidification temperature. Such residual stresses-compressive in one phase and tensile in the other, will certainly affect the mechanical properties of these in-situ composites. Residual stresses in directionally solidified $\mathrm{Al}_{2} \mathrm{O}_{3} / \mathrm{ZrO}_{2}\left(\mathrm{Y}_{2} \mathrm{O}_{3}\right)$ eutectic arise essentially from the thermal expansion mismatch between the $\mathrm{Al}_{2} \mathrm{O}_{3}$ and $\mathrm{c}-\mathrm{ZrO}_{2}\left(\mathrm{Y}_{2} \mathrm{O}_{3}\right)$ phases. ${ }^{10}$ The thermal expansion coefficient of $\mathrm{Al}_{2} \mathrm{O}_{3}$ and $\mathrm{c}-\mathrm{ZrO}_{2}\left(\mathrm{Y}_{2} \mathrm{O}_{3}\right)$ phases are $8 \times 10^{-6}$ and $12 \times 10^{-6}{ }^{\circ} \mathrm{C}^{-1}$ respectively and due to this substantial mismatch, large tensile residual stresses can accumulate in $\mathrm{c}-\mathrm{ZrO}_{2}\left(\mathrm{Y}_{2} \mathrm{O}_{3}\right)$ as the sample cools from solidification temperature to room temperature. A similar degree of thermal expansion mismatch occurs in $\mathrm{NiO} / \mathrm{ZrO}_{2}$ eutectic. Residual stresses on the order of one GPa were determined for $\mathrm{NiO} / \mathrm{ZrO}_{2}$ system. ${ }^{11}$ The magnitude of the residual stresses in $\mathrm{Al}_{2} \mathrm{O}_{3} / \mathrm{ZrO}_{2}\left(\mathrm{Y}_{2} \mathrm{O}_{3}\right)$ eutectic is expected to be of the same order of magnitude. In addition, $\mathrm{c}-\mathrm{ZrO}_{2}\left(\mathrm{Y}_{2} \mathrm{O}_{3}\right)$ is in residual tension and has much smaller creep activation energy than sapphire. ${ }^{89}$ If unconstrained, the $\mathrm{c}-\mathrm{ZrO}_{2}\left(\mathrm{Y}_{2} \mathrm{O}_{3}\right)$ phase would be capable of deforming a 
great deal faster than the eutectic due to its low activation energy and the superposition of the residual and applied external stresses. In order to maintain equal strain rates, the $\mathrm{c}-\mathrm{ZrO}_{2}\left(\mathrm{Y}_{2} \mathrm{O}_{3}\right)$ phase must relax by means of stress transfer to the $\mathrm{Al}_{2} \mathrm{O}_{3}$ phase. Therefore creep of $\mathrm{c}-\mathrm{ZrO}_{2}\left(\mathrm{Y}_{2} \mathrm{O}_{3}\right)$ phase occurs under a decreasing stress. The orientation relationship of the more creep resistant $\mathrm{Al}_{2} \mathrm{O}_{3}$ phase with respect to growth direction and the interfacial constraint between the lamella determines the rate of stress transfer. The rate of transfer of stress is expect to decrease until steady state is established, when both phases deform together at the same rate. However, the applied stress of $300 \mathrm{MPa}$ in Fig. 1 is large enough that steady state is not reached before failure occurs. Thus, the strain compatibility at the interphase interfaces determines the "constraint effect" and the creep rupture characteristic. It is difficult to predict the level of misfit between $\mathrm{Al}_{2} \mathrm{O}_{3}$ and $\mathrm{c}-\mathrm{ZrO}_{2}\left(\mathrm{Y}_{2} \mathrm{O}_{3}\right)$ phases at high temperatures. The anisotropic nature of $\mathrm{Al}_{2} \mathrm{O}_{3} / \mathrm{ZrO}_{2}\left(\mathrm{Y}_{2} \mathrm{O}_{3}\right)$ eutectic and magnitude of interfacial constraint between the two phases is not known a priori. Experiments to measure the strains using $\mathrm{x}$-ray diffraction techniques and to determine the residual stress tensor ${ }^{12}$ have been initiated.

The $\mathrm{Al}_{2} \mathrm{O}_{3} / \mathrm{ZrO}_{2}\left(\mathrm{Y}_{2} \mathrm{O}_{3}\right)$ system consists of one creep resistant (c-axis sapphire) and one easily deformed material $\left(\mathrm{c}-\mathrm{ZrO}_{2}\left(\mathrm{Y}_{2} \mathrm{O}_{3}\right)\right)$. Its is pertinent to compare the deformation characteristic of each phase in a single crystal form and contrast this with $\mathrm{Al}_{2} \mathrm{O}_{3} / \mathrm{ZrO}_{2}\left(\mathrm{Y}_{2} \mathrm{O}_{3}\right)$ eutectic. C-axis sapphire has excellent creep resistance. In contrast, single crystal $\mathrm{c}-\mathrm{ZrO}_{2}\left(\mathrm{Y}_{2} \mathrm{O}_{3}\right)$ is among the least creep resistant oxides, a consequence of its large number of active slip systems and rapid diffusion rates. The comparison of minimum creep rate between $\mathrm{Al}_{2} \mathrm{O}_{3} / \mathrm{ZrO}_{2}\left(\mathrm{Y}_{2} \mathrm{O}_{3}\right.$ ) eutectic (Fig. 2) and single crystal $\mathrm{c}-\mathrm{ZrO}_{2}\left(\mathrm{Y}_{2} \mathrm{O}_{3}\right)$ data from Martinez-Fernandez et al ${ }^{9}$ reveals that the eutectic is an order of magnitude more creep resistant than the single crystal $\mathrm{c}-\mathrm{ZrO}_{2}\left(\mathrm{Y}_{2} \mathrm{O}_{3}\right)$. In view of the above discussion about the large residual tensile stresses within the $\mathrm{c}-\mathrm{ZrO}_{2}\left(\mathrm{Y}_{2} \mathrm{O}_{3}\right)$ phase, the superior creep resistance of $\mathrm{Al}_{2} \mathrm{O}_{3} / \mathrm{ZrO}_{2}\left(\mathrm{Y}_{2} \mathrm{O}_{3}\right)$ eutectic indicate that the two phases must remain well bonded at the coherent interfaces even at very high temperatures. The present level of information about the microstructure 
of $\mathrm{Al}_{2} \mathrm{O}_{3} / \mathrm{ZrO}_{2}\left(\mathrm{Y}_{2} \mathrm{O}_{3}\right)$ eutectic ${ }^{19}$ and the understanding of the interaction of the individual phases in the creep process require further study.

Even though the majority of the sapphire phase is c-axis oriented and that coincident with the growth direction, there are some regions of intercolony boundaries and small "unfavorably" oriented colonies which are overgrown by more rapidly growing neighbors, have an off-axis orientation and therefore have stress trajectories on the slip planes. Accordingly, it is important to consider the deformation characteristic of off-axis sapphire and the potential contribution to eutectic deformation. The off-axis oriented sapphire (Fig. 1) shows no transient behavior at the temperature and stress level studied (no incubation period), giving an immediate steady state response, that may also include a tertiary acceleration. The creep behavior of the $\mathrm{Al}_{2} \mathrm{O}_{3} / \mathrm{ZrO}_{2}\left(\mathrm{Y}_{2} \mathrm{O}_{3}\right)$ eutectic is markedly different. As will be discussed below, this may be due to creep-strain-induced-relaxation of thermal misfit stresses in the $\mathrm{c}-\mathrm{ZrO}_{2}\left(\mathrm{Y}_{2} \mathrm{O}_{3}\right)$ phase - analogous in some ways to the unusual transient creep behavior of the CMSX-3 superalloy single crystal studied by Pollock and Argon. ${ }^{20}$ The absence of the incubation period in eutectic creep suggest that a sufficient population of dislocations are readily generated possibly in both phases of the eutectic; $\mathrm{Al}_{2} \mathrm{O}_{3}$ and $\mathrm{c}-\mathrm{ZrO}_{2}\left(\mathrm{Y}_{2} \mathrm{O}_{3}\right)$. Furthermore, the above cited description of the interphase characteristics require the compatibility of deformation and slip processes must develop independently in the two phases because the magnitudes of the Burger's vectors of the respective dislocations are sufficiently different that slip in the two components must remain isolated across the interfaces. This should give rise to channeling of dislocations.

Channeling of dislocations has been observed in partially stabilized $\mathrm{ZrO}_{2}$ by Martinez-Fernandez et al. ${ }^{9}$ Formation of elongated precipitates of tetragonal $\mathrm{ZrO}_{2}$ inhibit dislocation movement leading to the observed dislocation channeling. Clearly, such enforced channeling will be an important source of creep resistance of these eutectics and may resemble the channeling behavior of slip in the $\gamma$ component of the CMSX-superalloy crystals reported by Pollock and Argon. ${ }^{20}$ The closed spatial arrangement of lamella in the eutectics suggests that the effect of Orowan's resistance to dislocation 
motion, if any, also needs to be considered here. The $\mathrm{Al}_{2} \mathrm{O}_{3} / \mathrm{ZrO}_{2}\left(\mathrm{Y}_{2} \mathrm{O}_{3}\right)$ eutectic composition can be considered as lamellae of $\mathrm{ZrO}_{2}\left(\mathrm{Y}_{2} \mathrm{O}_{3}\right)$ surrounded by the more creep resistant sapphire. To force the dislocations through the $\mathrm{c}-\mathrm{ZrO}_{2}\left(\mathrm{Y}_{2} \mathrm{O}_{3}\right)$ phase in $\mathrm{Al}_{2} \mathrm{O}_{3} / \mathrm{ZrO}_{2}\left(\mathrm{Y}_{2} \mathrm{O}_{3}\right)$ eutectic, the applied stress must increase to overcome the local Orowan resistance of the lamellae; ${ }^{20}$

$$
\tau_{\mathrm{or}}=\sqrt{\frac{2}{3}} \frac{\mu \mathrm{b}}{\lambda}
$$

Where $\mu$ is the shear modulus, $b$ is the Burger's vector, and $\lambda$ is the lamella thickness. Using $\mu=36$ $\mathrm{GPa}, \mathrm{b}=0.363 \mathrm{~nm}^{8.9}$ and taking the lamellae size $\lambda=0.2 \mu \mathrm{m}$ gives an Orowan resistance of approximately $53 \mathrm{MPa}$. Dividing by the appropriate Schmid factor, a uniaxial applied stress of the order of $100 \mathrm{MPa}$ is required for bowing dislocations around the typical lamella of the size of 0.2 $\mu \mathrm{m}$. The estimated level of stress due to the lamella size is small and may be negligible compared to the anticipated residual tensile stress in $\mathrm{c}-\mathrm{ZrO}_{2}\left(\mathrm{Y}_{2} \mathrm{O}_{3}\right)$. Further experimental study is required to assess the role of dislocations in conjunction with the unique phase geometry of eutectic ceramics and specifically the role of dislocations at the interfaces. Even though the magnitude of the stress in the $\mathrm{Al}_{2} \mathrm{O}_{3} / \mathrm{ZrO}_{2}\left(\mathrm{Y}_{2} \mathrm{O}_{3}\right)$ system due to Orowan's resistance is low compared to residual and applied stresses, the trend toward improved creep behavior with decreasing lamella size is expected to have further significance for directionally solidified eutectic ceramics in general. The advantage of small lamellae size eutectics is reflected in both improved resistance to dislocation motion and superior strength.

The above discussion tacitly assumes that the $\mathrm{Al}_{2} \mathrm{O}_{3}$ phase will not deform and the impenetrability of the sapphire is key to this type of improved creep resistance. The experimentally observed deformation characteristics and the creep data for the $\mathrm{Al}_{2} \mathrm{O}_{3} / \mathrm{ZrO}_{2}\left(\mathrm{Y}_{2} \mathrm{O}_{3}\right)$ system indicate that degree of departure from [0001] orientation of alumina are predominantly responsible for the level of creep resistance observed for the eutectic. One strategy to achieve superior creep properties is then to establish growth conditions for which the $\mathrm{Al}_{2} \mathrm{O}_{3}$ growth axis is more strictly aligned along the c-axis 
$(<0001>$ direction $)$. An example of improved $<0001>$ texture is shown in Fig. 4. Faceting of the alumina growth front results in a three-fold symmetrical arrangement of phases. The favorable creep resistance properties reported in Figures 1 and 2 can be further improved by eliminating the colony boundaries. Eliminating the colony boundaries to improve creep resistance will also produce stronger eutectics because the room temperature strength limiting flaws of $\mathrm{Al}_{2} \mathrm{O}_{3} / \mathrm{ZrO}_{2}\left(\mathrm{Y}_{2} \mathrm{O}_{3}\right.$ frequently occur in these regions.

Successful structural exploitation of the $\mathrm{Al}_{2} \mathrm{O}_{3} / \mathrm{ZrO}_{2}\left(\mathrm{Y}_{2} \mathrm{O}_{3}\right)$ system will require a detailed understanding of strength behavior as a function of time and temperature. Figure 7 shows that the $\mathrm{Al}_{2} \mathrm{O}_{3} / \mathrm{ZrO}_{2}\left(\mathrm{Y}_{2} \mathrm{O}_{3}\right)$ eutectic does not exhibit the precipitous strength losses at elevated temperature which in part limits the usefulness of sapphire. The tensile strength of $\mathrm{Al}_{2} \mathrm{O}_{3} / \mathrm{ZrO}_{2}\left(\mathrm{Y}_{2} \mathrm{O}_{3}\right)$ eutectic is comparable to the tensile strength of $\mathrm{c}-\mathrm{ZrO}_{2}\left(\mathrm{Y}_{2} \mathrm{O}_{3}\right)$ at elevated temperatures. ${ }^{10}$ The high temperature strength retention shows that the mechanical properties of a two phase eutectic can be superior to either constituent alone. Prediction of the limits and capabilities of directionally solidified eutectic ceramics is an area that mandates increased attention of theoreticians if these materials are ever to gain acceptance for high temperature structural applications. The challenges to achieve controlled microstructures and minimization of inhomogeneous residual stresses are essential to produce eutectics that exhibit their inherent potential.

\section{CONCLUSION}

The $\mathrm{Al}_{2} \mathrm{O}_{3} / \mathrm{ZrO}_{2}\left(\mathrm{Y}_{2} \mathrm{O}_{3}\right)$ eutectic maintains a low energy interface resulting from directional solidification and can produce strong and stable reinforcing phase/matrix bonding. The high temperature microstructural stability, large aspect ratio and strong interphase bonding found in $\mathrm{Al}_{2} \mathrm{O}_{3} / \mathrm{ZrO}_{2}\left(\mathrm{Y}_{2} \mathrm{O}_{3}\right)$ eutectic contributes to it's superior creep resistance, compared to that of conventional ceramics. The phases comprising a eutectic are thermodynamically compatible at 
higher homologous temperatures than man-made composites and as such offer the potential for superior high temperature properties. 


\section{REFERENCES}

1. V. S. Stubican and R. C. Bradt, Ann. Rev. Mater. Sci., 11 (1981) 267.

2. A. Sayir and L. E. Matson, in HITEMP Review Vol. 1 NASA CP-10082, (1992) pp. 83.1.

3. A. Sayir, R. M. Dickerson, H. M. Yun, S. Heidger and L. E. Matson, in HITEMP Review Vol. 1, NASA CP-10146, (1994) pp. 74.1.

4. A. Sayir and S. C. Farmer, in "Ceramic Matrix Composites-Advanced High-Temperature Structural Materials," eds., R. A Lowden, M. K. Ferber, J. R. Hellmann, K. K. Chawla, and S. G. DiPietro, Mat. Res. Soc. Proc., 365 (1995) 11.

5. A. Sayir, in Computer Aided Design of High-Temperature Materials, Eds.A. Pechenik, R. K. Kalia, and P. Vashista, Oxford University Press (1999) pp.197.

6. A. Sayir and S. C. Farmer, in "Ceramic Matrix Composites-Advanced High-Temperature Structural Materials," eds., R. A Lowden, M. K. Ferber, J. R. Hellmann, K. K. Chawla, and S. G. DiPietro, Mat. Res. Soc. Proc., 365 (1995) 22.

7. A. Sayir, J. B. Hurst, and S. Jones, in Proc. of the $2^{\text {nd }}$ Ann. HITEMP Rev. (1989), NASA Conference Publication 10039.

8. D. Gomez-Garcia, J. Martinez-Fernandez, A. Dominguez-Rodriguez, P. Eveno and J. Castaing, Acta Mater., 44 [3] (1996) 991.

9. J. Martinez-Fernandez, M. Jimenez-Melendo, A. Dominguez-Rodriguez, K. P. D. Lagerlof, and A. H. Heuer, Acta Metall. Mater., 41 (11) (1993) 3171.

10. K. J. McClellan, H. Sayir, A. H. Sayir and A. Sayir, Ceram. Engng. Sci. Proc., 14 (1993) 651.

11. E. Dickey, C. S. Frazer, T. R. Watkins and C. R. Hubbard, J. Europ. Ceram. Soc., 19 (1998) 2503.

12. E. Dickey and A. Sayir, unpublished work.

13. L. Mazerolles, D. Michel, and R. Portier, J. Am. Ceram. Soc., 69 [7-8] (1992) 190.

14. S. C. Farmer, A. Sayir and P. O. Dickerson, Symp. Proc. In-Situ Composites-Sci\&Techn., TMS, Warrendale PA (1993) 167-182. 
15. M. Fragneau, and A. Revcolevschi, J. Am. Ceram. Soc., 66 (1983) C-162.

16. M. Fragneau, A. Revcolevschi, and D. Michel, J. Am. Ceram. Soc., 65 (1982) C-102.

17. L. Mazerolles, D. Michel, M. Cornier, R. Porties., Interfaces Between Zirconia and Refractory Oxides, In Advances in Ceramics. 1988. The Am. Ceram. Soc. Inc.

18. L. A. Tietz and C. B. Carter, Phil. Mag., A 67 (1993) 729.

19. S. C. Farmer and A. Sayir, R. M. Dickerson, L. E. Matson, accepted for publication in Proc. of $24^{\text {th }}$ Ann. Int. Conf. on Adv. Ceram. and Composites, Am. Ceram. Soc. 2000.

20. T. M. Pollock and A. S. Argon, Acta Metall. Mater., 40 (1) (1992) 1. 


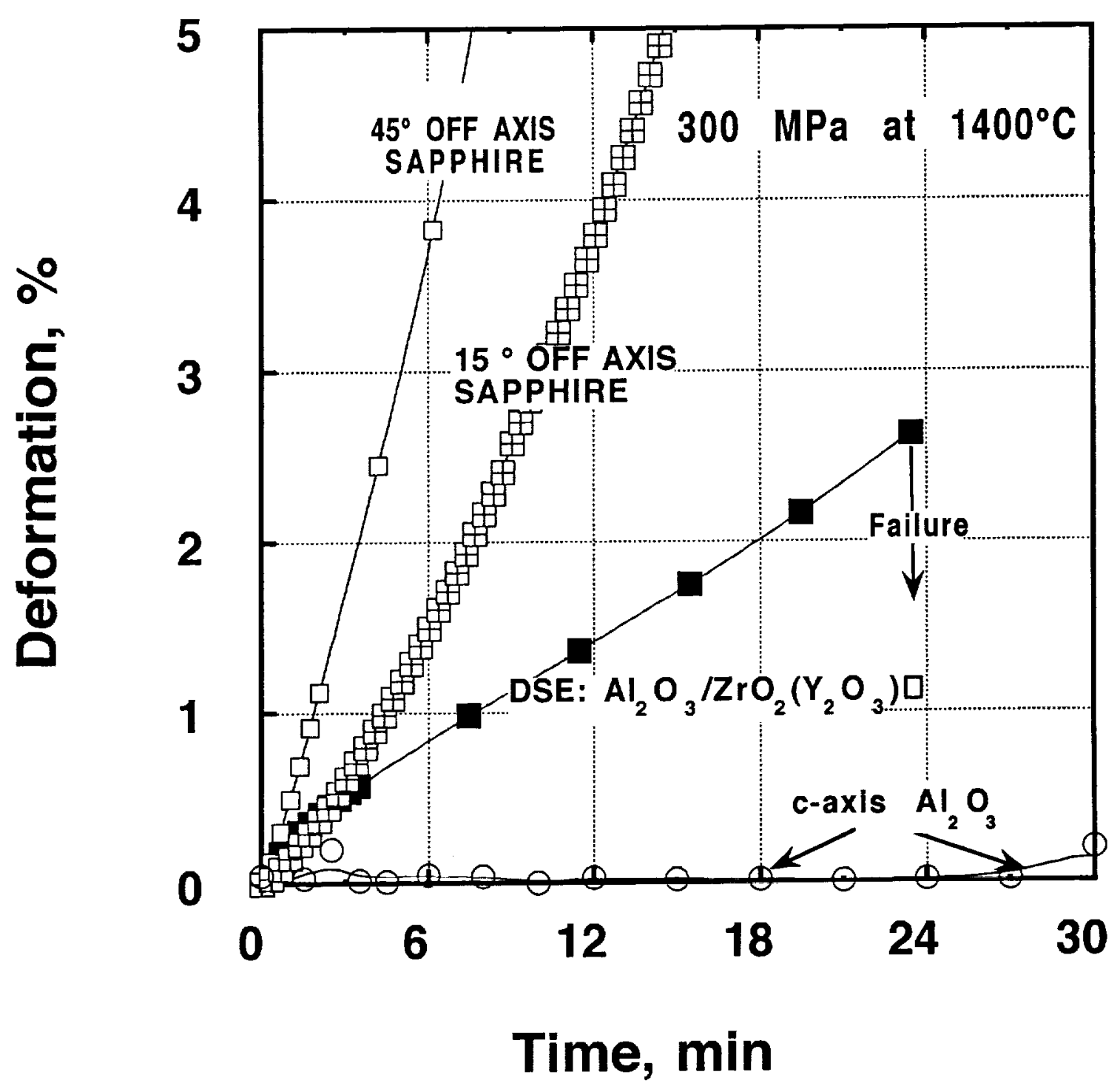

Fig.1 Creep deformation $\mathrm{Al}_{2} \mathrm{O}_{3} / \mathrm{ZrO}_{2}\left(\mathrm{Y}_{2} \mathrm{O}_{3}\right)$ and sapphire at $1400^{\circ} \mathrm{C}$ and $300 \mathrm{MPa}$. 


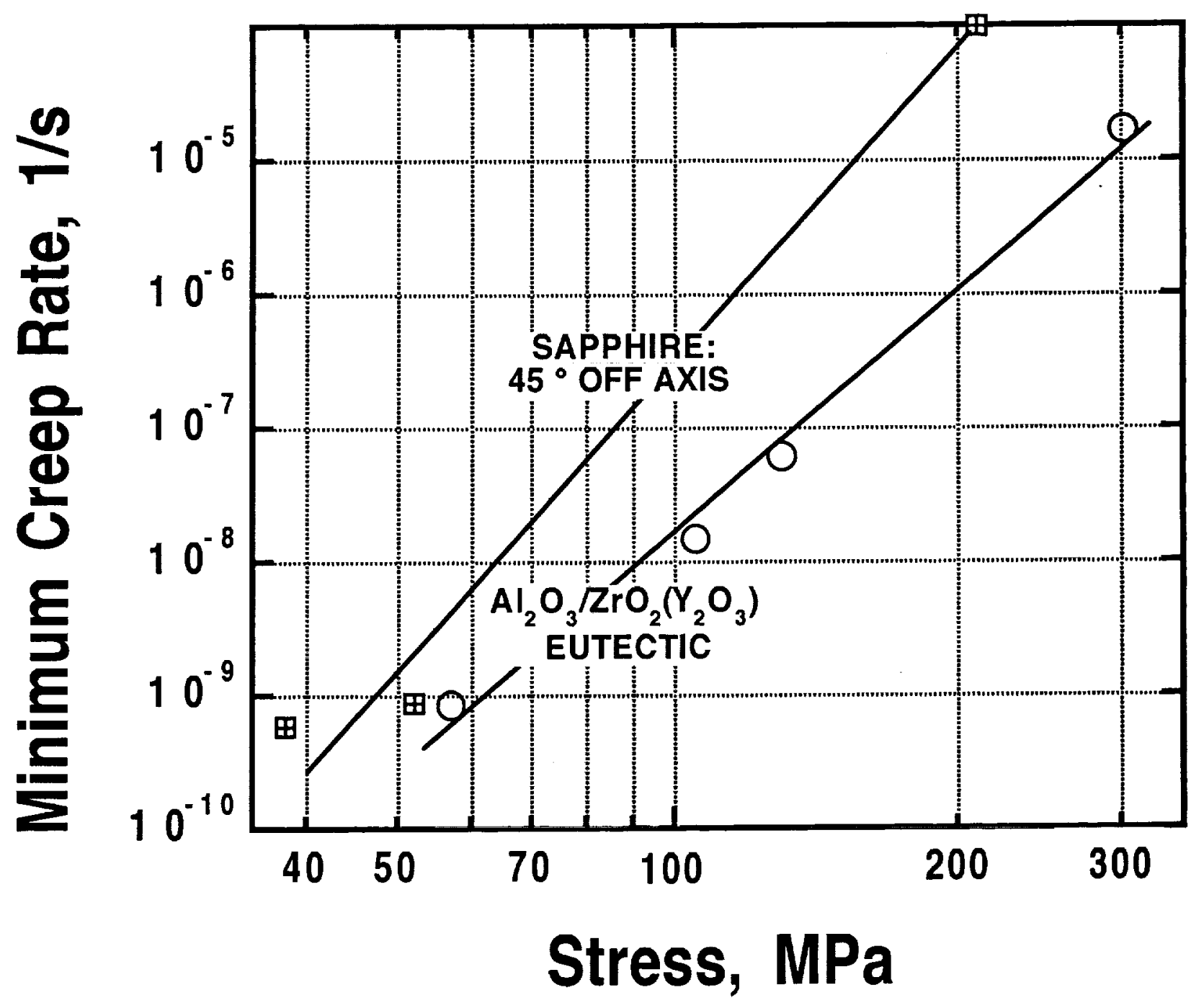

Fig.2 Minimum creep rate at $1400^{\circ} \mathrm{C}$. 


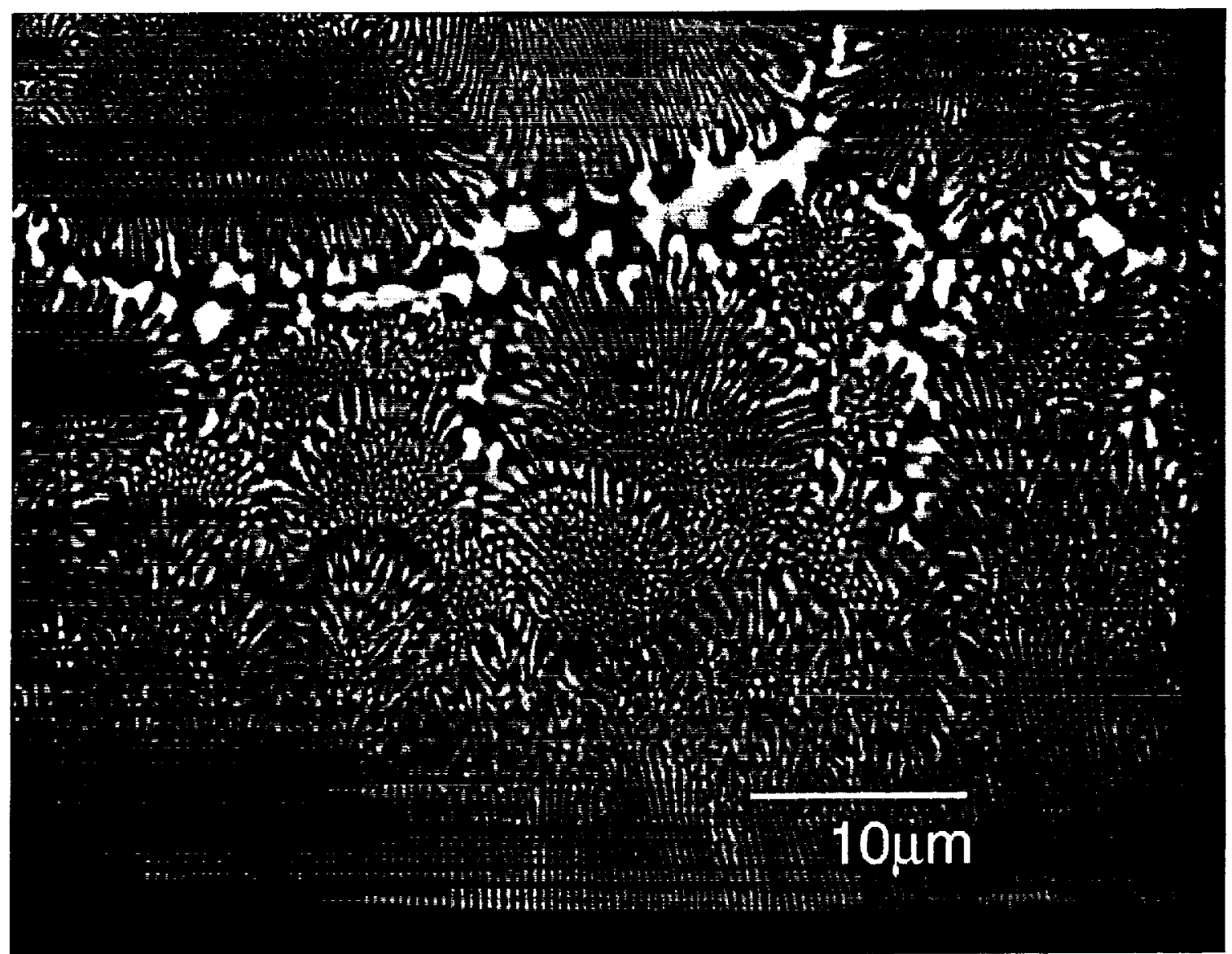

Fig.3 Colonies in $\mathrm{Al}_{2} \mathrm{O}_{3} / \mathrm{ZrO}_{2}\left(\mathrm{Y}_{2} \mathrm{O}_{3}\right)$. 


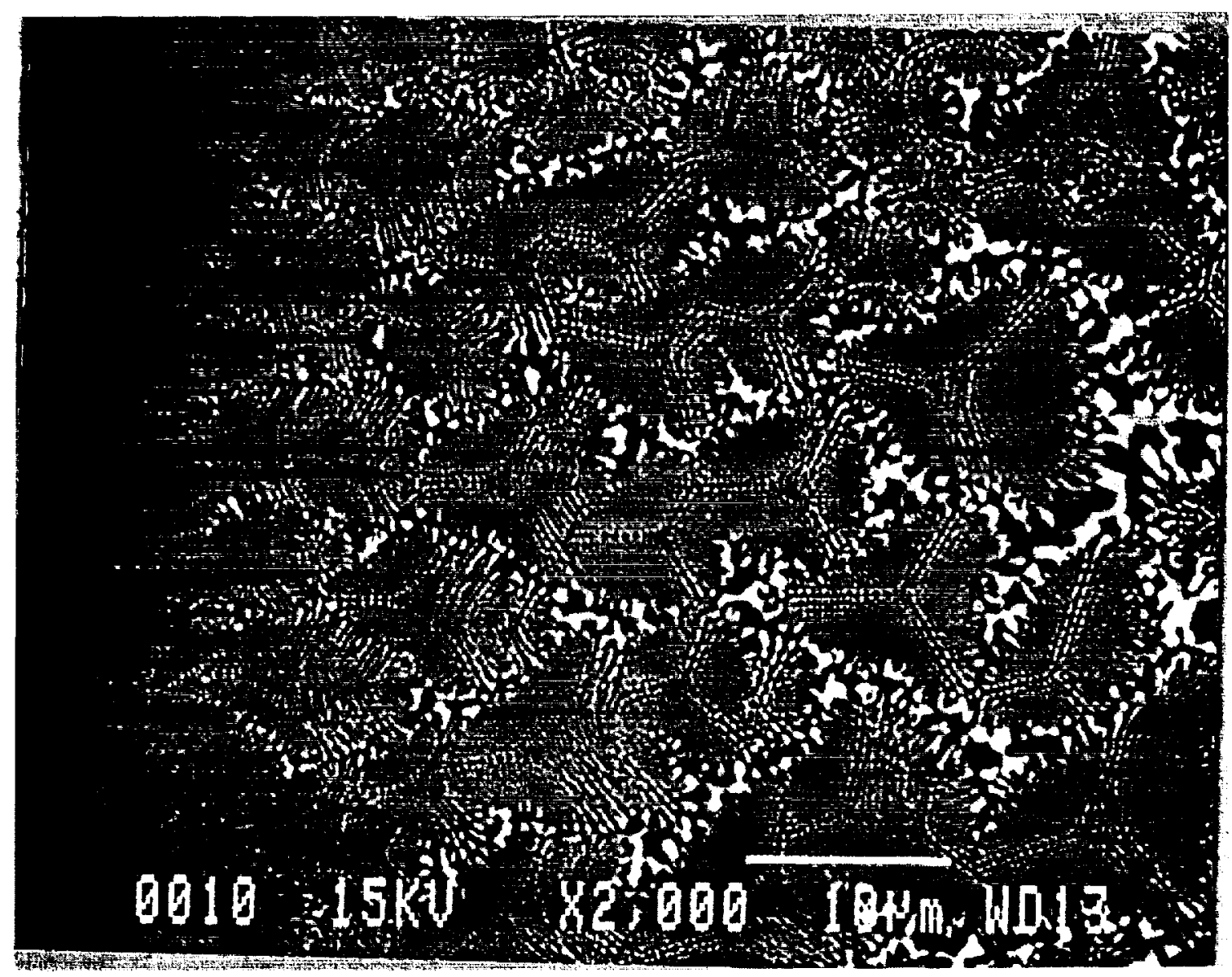

Fig.4 Faceted colonies in $\mathrm{Al}_{2} \mathrm{O}_{3} / \mathrm{ZrO}_{2}\left(\mathrm{Y}_{2} \mathrm{O}_{3}\right)$. 


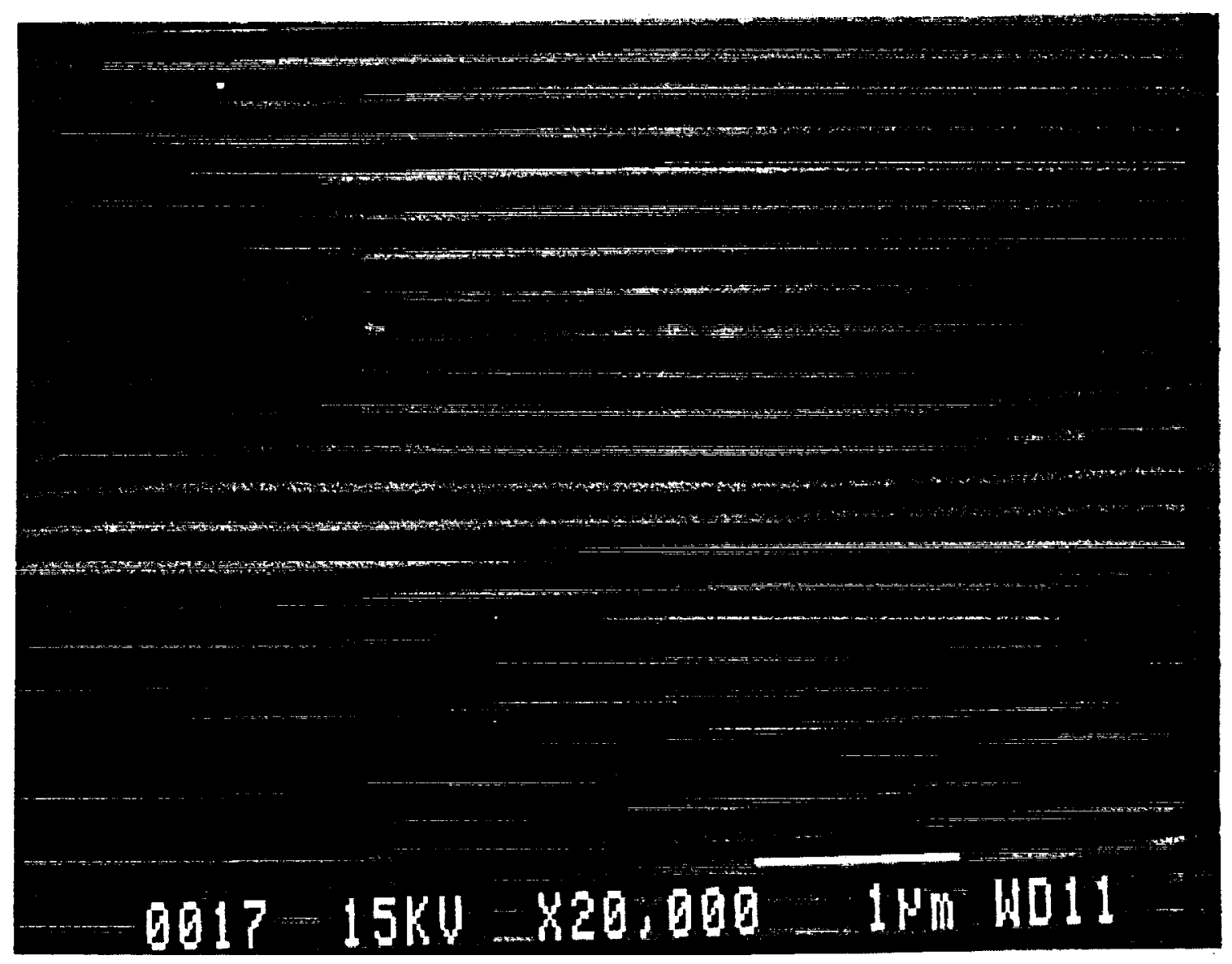

Fig. 5 Fine outer lamella in $\mathrm{Al}_{2} \mathrm{O}_{3} / \mathrm{ZrO}_{2}\left(\mathrm{Y}_{2} \mathrm{O}_{3}\right)$. 

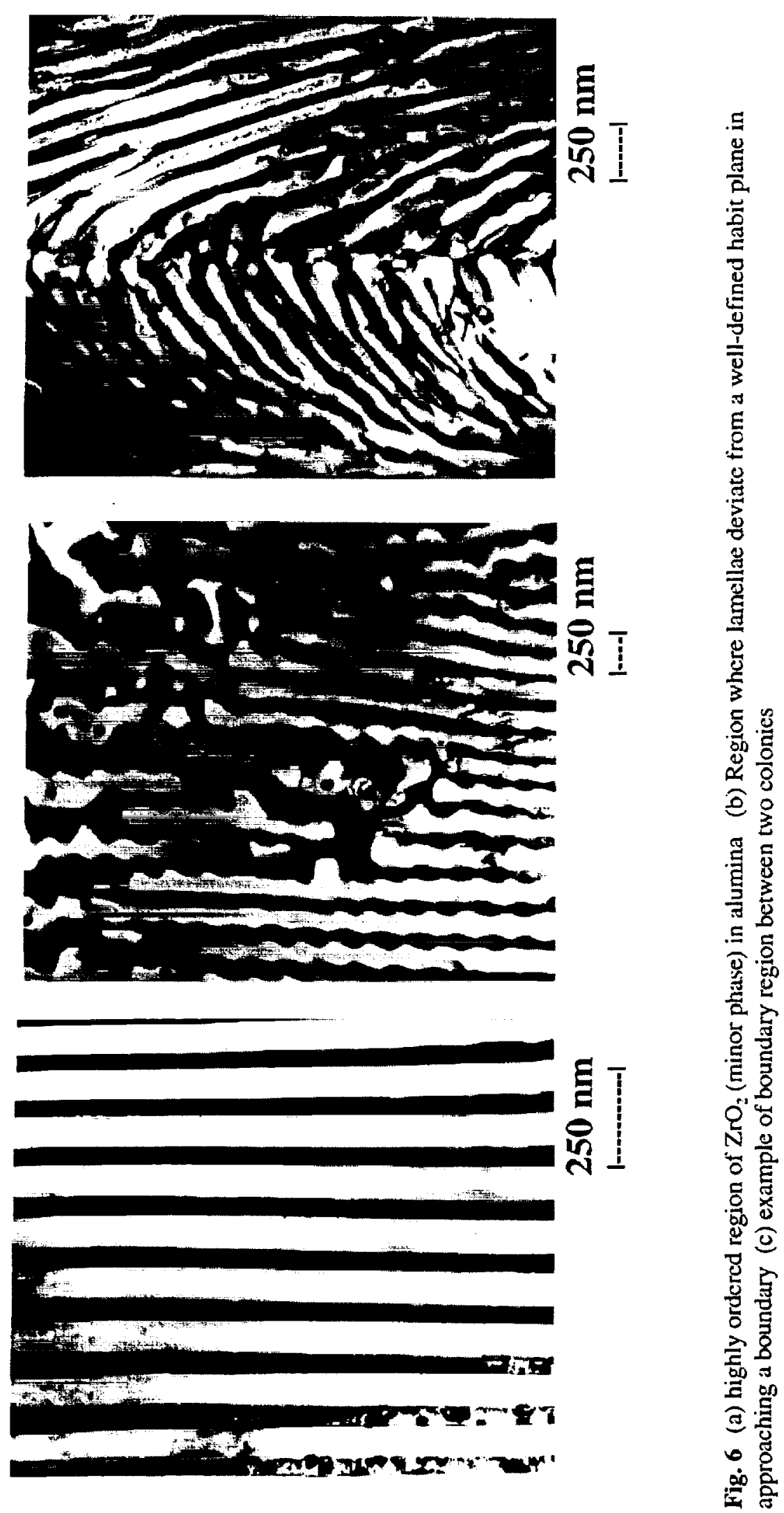


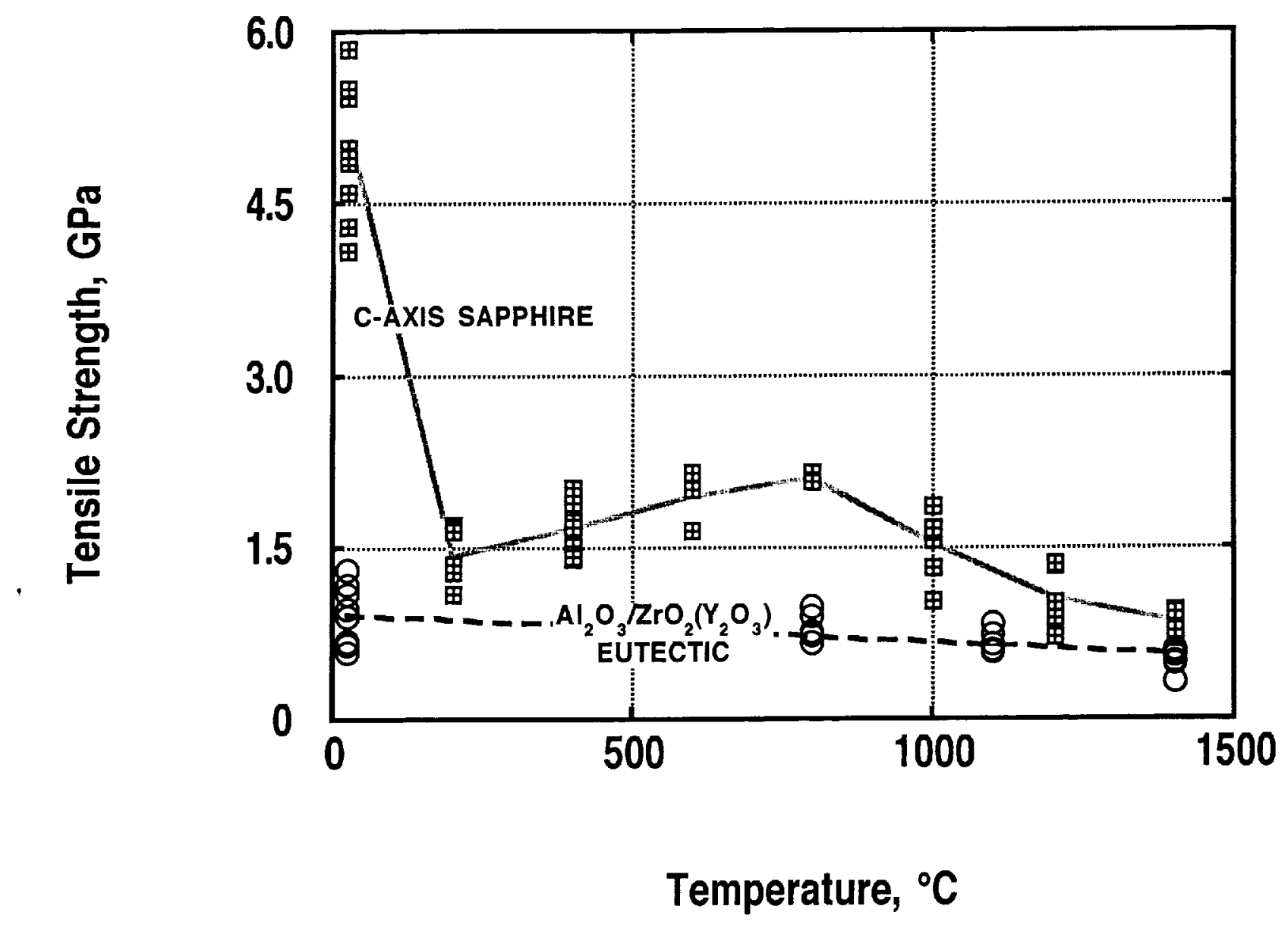

Tensile cresues

Fig.7 Strength at temperature. 